Debreceni Egyetem, Fogorvostudományi Kar, Parodontológiai Tanszék* ÉP-DENT Fogászati és Szájsebészeti Klinika**

Debreceni Egyetem, Fogorvostudományi Kar, Fogpótlástani Tanszék ${ }^{\star \star *}$

\title{
Az orális egészséghez kapcsolódó életminőség összefüggése a parodontális státusszal
}

\author{
DR. SÁRI KINGA DOROTTYA*, DR. KÓRÓDI ÁGNES**, DR. MOHÁCSI RITA***, DR. ANGYAL JÁNOS*
}

Irodalmi adatok szerint a parodontális kórképek befolyásolhatják az orális egészséghez kapcsolódó életminőséget. Fogorvosi vonatkozásban az életminőség mérésére leggyakrabban az OHIP kérdőívet használják, amelynek segítségével a parodontális elváltozások egészségtudatra kifejtett hatása is vizsgálható.

Az OHIP-14 kérdőív adaptált változatával 45 beteg (29 krónikus parodontitises, 16 egészséges) életminőségi jellemzőit tanulmányoztuk. Vizsgálatunk során szoros összefüggést találtunk a parodontális kórképek jelenléte, illetve az esztétikai problémák, a diszkomfort érzés, a szájüregi fájdalom jelenléte és a funkcionális korlátozottság között. A fájdalom, valamint az ínyvérzés és a szondázási mélység között a moláris és a front régióban egyaránt pozitív összefüggés volt kimutatható. A funkcionális korlátozottság előfordulása szignifikáns korrelációt mutatott a hiányzó fogak számával, az ínyvérzéssel, illetve a szondázási mélységgel.

Eredményeink alapján elmondható, hogy a parodontális megbetegedések feltételezhetően közrejátszanak az életminőség bizonyos paramétereinek csökkenésében. Ebből következően a fogágybetegségek klinikai vizsgálata során indokolt az életminőségre vonatkozó jellemzőkre is rutinszerűen rákérdezni.

Kulcsszavak: OHIP-14, életminőség, parodontális állapot, orális egészség

\section{Bevezetés}

A parodontális megbetegedések számos tünettel járnak, amelyek befolyásolhatják az orális egészséggel összefüggő életminőséget [21]. Az életminőség hatással van a személy öngondoskodási, önellátó képességére, illetve a beteg szociális viszonyaira, kulturális és környezeti tényezőire $[21,26]$. Vizsgálatára számos kérdőívet fejlesztettek ki [3, 6, 19, 31], az egyik leggyakrabban használt a Locker és Slade [20] által kifejlesztett Oral Health Impact Profile (OHIP) [15, 31, 34, 35]. Az Oral Health Impact Profile (OHIP) alkalmazásával a páciens orális életminőségét határozhatjuk meg, a beteg válaszai alapján összegzett pontértékkel. Hazai szerzők szintén ezt a módszert alkalmazták a protetikai kezelés életminőségre gyakorolt hatásának vizsgálata során [16, 32]. Ezen kérdőívben hangsúlyozott szerepet kap a funkcionális korlátozottság, a fájdalom- és a diszkomfortérzés jelenléte, a fizikai, pszichológiai, szociális deficit és hátrány kapcsolatának vizsgálata. Több nemzetközi publikáció foglalkozik a parodontális megbetegedések életminőséget csökkentő hatásának kérdőives vizsgálatával is [2, 5, 8, 21, 29]. Zanatta és mtsai rögzített fogszabályozó készülékes kezelések során kialakult gingiva hyperplasia és vérzés életminőségi mutatókra gyakorolt hatását vizsgálták [35]. Tudományos vizsgálatokban foglalkoznak a munkából való kiesés fogazati állapottal összefüggő okaival is [27].

A parodontális kórképek kialakulását és az életminőséget sok tényező befolyásolja, így nehéz a parodontális státusz pontos hatását megítélni $[21,26]$. Wong és mtsai a nem sebészi parodontális kezelést pozitív hatásúnak találták az életminőségre, és különösen a fájdalommal, valamint a pszichés állapottal kapcsolatos mutatókban figyeltek meg jelentős javulást [34]. Lényeges, hogy a fogorvos felmérje a páciensek egészségtudatát, illetve tájékozódjon arról, hogy a beteg panaszai mennyire okoznak változást az életminőségben. Szükséges továbbá, hogy a gyógyulás érdekében értékeljük a beteg kezeléshez való hozzáállását, az állapotára vonatkozó véleményét és a motiváltságát. Ezek segítségével célirányosan motiválható, instruálható és eredményesebben kezelhető a beteg [28]. Ugyanakkor a fogágybetegség jelenléte és a vonatkozó életminőségi mutatók között a magyar szakirodalomban nem találtunk publikált eredményeket.

Jelen munkánk célkitűzése annak értékelése, hogy van-e összefüggés a páciensek parodontális státusza és az orális életminőségi mutatók között. Klinikai és kérdőíves módszerekkel vizsgáltuk, hogy a parodontális kórképek jelenléte milyen hatással van a betegek egészségtudatára, mindennapi tevékenységére, száj- 
üregi diszkomfort érzetére és a rágórendszeri funkcióira.

\section{Beteganyag és módszertan}

A betegeket a Debreceni Egyetem Fogorvostudományi Kar Parodontológia Tanszékére érkező páciensekből választottuk ki. A meghatározott vizsgálati kritériumoknak 45 fö felelt meg, öket két csoportba osztottuk, egy 29 fős krónikus parodontitises kísérletes csoportra és egy 16 fös kontroll csoportra. A kísérletben azon betegek vehettek részt, akik anamnézisében nem szerepelt fertőző-, szív- és érrendszeri-, reumás-, idegrendszeri-, allergiás- és egyéb más szisztémás megbetegedés. További kizáró tényező volt azon gyógyszerek szedése, amelyek a parodontális státusz és a rágóapparátus állapotát befolyásolhatták [5]. A parodontitises kísérletes csoportba csak olyan betegek kerültek, akik azt megelőzően még nem részesültek parodontológiai szakellátásban. A vizsgálatba nem lettek bevonva a frontfoghiánnyal rendelkezők, az elégtelen híd- és kivehető pótlást viselők, illetve azok, akiknél nem dentális eredetű orofaciális fájdalommal járó kórkép került azonosításra. A parodontitises csoportba azon betegek kerülhettek, akiknél legalább két kvadráns esetén minimum $6 \mathrm{~mm}$-es szondázási mélységet mértünk [8]. A kísérletben résztvevők átlagéletkora a kísérleti és a kontroll csoportokban $45,45 \pm 13,69$, illetve 34,56 $\pm 16,45$ év volt.

A fogászati anamnézist követően részletes státuszfelvételt végeztünk, majd stomato-onkológiai vizsgálatot, amelyet a száj higiénés- és parodontális állapotának vizsgálata követett. A dentális plakk, a szondázásra történő ínyvérzés vizsgálata és a szondázási mélység mérése négy felszínen történt. A supra- és subgingivális fogkő jelenléte, az ínyrecesszió, a furkációérintettség és a fogmobilitás kvantitatív leírással történt.

A szondázásra jelentkező ínyvérzés jelenlétének meghatározására az Ainamo-Bay indexet alkalmaztuk [1]. A négy mérési pont szondázása után a vérző felszínek számát az összes vizsgált felszínek számához képest fejeztük ki, százalékban megadva azt. Hasonlóan a plakk jelenlétét vagy hiányát rögzítve, határoztuk meg a plakkindexet is [1].

A parodontális szondázási mélységet kalibrált Williams parodontális szondával (Astir Intermedica, Kensington, Anglia) határoztuk meg, a szabad ínyszél és a parodontális sulcus bázisa közötti távolság mm-ben kifejezett értéke formájában. Foganként 4 mérési ponton (3 buccális és 1 palatinális) végeztünk mérést [2]. Ugyanezt a kalibrált szondát használtuk az ínyreceszszió értékelésére is, amelynek kiterjedését a gingiva marginalis legmélyebb pontja és a zománc-cement határ távolsága adta mm-ben kifejezve. A fogkő jelenlétét Greene-Vermillion-indexszel határoztuk meg, amelynek során a fogfelszínt három harmadra osztottuk, és az értékek, a fogkővel fedett felszín kiterjedésétől füg- gően, 0 és 3 között voltak [10]. A 0 a fogkő hiányát, 1 a gingivális harmadban, 2 a gingivális és centrális harmadban elhelyezkedő fogkövet, vagy az elszórtan meglévő subgingivális fogkövet jelölte, és 3-mal jelöltük, amikor a fogkő a fognak több mint kétharmad részét borította vagy a subgingivális fogkő összefüggő réteget alkotott. A furkációérintettséget speciális, hajlított parodontális szondával vizsgáltuk (Nabers-féle szonda, Aesculap AG, Tuttlingen, Németország). Elsőfokú furkációérintettség esetén a szonda gyökéroszlásba történő penetrációja nem haladta meg a 2 mm-t, illetve a fog szélességének egyharmadát, másodfokú érintettségnél meghaladta ugyan az egyharmadot, de a szonda még nem volt átvezethető, a harmadfokú érintettség pedig a gyökéroszlás átjárhatóságát jelentette [11]. A fogakat mobilitásuk szerint 4 csoportba soroltuk, 0 értéket kapott a fog, ha jól ült az alveolusban és csak fiziológiás mértékben volt mozgatható, 1-et, ha mozgathatósága nem haladta meg az $1 \mathrm{~mm}$-t, 2-t, ha $1 \mathrm{~mm}$-nél nagyobb mértékű volt a kitérés, és 3-at, ha vertikális mozgathatóság is észlelhető volt [24].

A kérdőíves vizsgálat az OHIP-14 kérdőívével történt, melynek segítségével mérhetővé váltak - a beteg szubjektív véleménye alapján - a szájegészségi állapot szociális hatásai, illetve az ahhoz kapcsolódó életminőség [21, 30, 31]. Négy témakörben csoportosítottuk a kérdéseket, amelyek a korlátozott funkcióra, a kényelmetlenség-érzésre, a fájdalom jelenlétére, a mindennapi tevékenységek akadályozottságára vonatkoztak. A szélesebb körű felmérés érdekében parodontológiai kórképekre vonatkozó kérdésekkel is kibővítettük a tesztet, így a résztvevők 23 kérdésre válaszoltak (1. táblázat). A kérdőív kitöltését a betegek segítségünkkel végezték, ezáltal elkerülhetővé vált a kérdések félreértelmezése. Az egyes kérdéskörökhöz több alpont tartozott, ezek alapján korlátozott funkcióra, kényelmetlenség-érzésre, a fájdalomra, a mindennapi tevékenységek akadályozottságára, valamint az esztétikára vonatkozóan csoportosítottuk a kérdéseket. Minden kérdésre 5 lehetséges választ lehetett adni: „mindig”, „gyakran”, „alkalmanként”, „nagyon ritkán”, „,soha”. A válaszok 4, 3, 2, 1, 0 pontot értek, vagyis a "mindig" 4 pontot, a „soha” válasz 0 pontot jelentett.

Kutatásunk során meghatározásra kerültek egyes statisztikai mutatók, a számtani közép, illetve a szórás is. A függetlenségvizsgálat érdekében Pearson-féle khinégyzet próbát hajtottunk végre Yates-féle korrekció nélkül, 5\%-os szignifikanciaszinttel. A paraméteres eljárások esetén, a több független mintára való figyelem miatt 5\%-os szignifikanciaszint mellett egyszempontos szóráselemzés (ANOVA) vizsgálatot végeztünk.

\section{Eredmények}

A vizsgált személyek száma összesen 45 fő volt. A kontroll csoportba 16 fö került, a krónikus parodontitisben szenvedők csoportját pedig 29 fő alkotta. 
1. táblázat

Az Oral Health Impact Profile kérdőiv (1-tól 14-ig számozott kérdés) parodontológiai vonatkozású kérdésekkel (kérdések 15-től 23-ig) kiegészített változata.

$A$ válaszlehetöségek számkódoltak, az alábbiak szerint: soha (0), nagyon ritkán (1), alkalmanként (2), gyakran (3), mindig (4).

\begin{tabular}{|l|}
\hline $\begin{array}{c}\text { Tapasztalta-e az alábbiakat } \\
\text { fogai-vagy szája állapota miatt? } \\
\text { Válaszát pontozza a következőképpen } \\
\text { (soha }=0, \text { nagyon ritkán }=1, \text { alkalmanként }=2, \\
\text { gyakran }=3, \text { mindig }=4)\end{array}$ \\
\hline 1. Beszédzavar \\
\hline 2. Ízérzés zavar \\
\hline 3. Szájüregi fájdalom \\
\hline 4. Rágási érzékenység \\
\hline 5. Kényszeresen odafigyelt a fogaira vagy szájállapotára \\
\hline 6. Feszültnek érezte magát \\
\hline 7. Étkezési probléma, pl: rágást igénylő ételek fogyasztásakor \\
\hline 8. Abba kellett hagynia az étkezést \\
\hline 9. Akadályozott volt a pihenése, kikapcsolódása \\
\hline 10. Zavarba jött mások elött \\
\hline 11. Ingerlékeny volt másokkal \\
\hline 12. Akadályozta a rendszeres feladatainak ellátását \\
\hline 13. Elégedetlen volt az életével \\
\hline 14. Teljes elkeseredettséget és kilátástalanságot érzett \\
\hline 15. Zavarta, vagy aggódott ínyvérzése miatt \\
\hline 16. Zavarta az ínyének a színe \\
\hline 17. Zavarta az ínysorvadása, a fogak „meghosszabbodása” \\
\hline 18. Zavarták fogkövei \\
\hline 19. Zavarta ínyének duzzanata \\
\hline 20. Zavarta fogainak elvándorlása, résképzödés fogai között \\
\hline 21. Zavarta fogainak kilazultsága \\
\hline 22. Zavarta az ételdarab beszorulása a fogai közé \\
\hline 23. Kellemetlenül érezte magát szájszaga miatt \\
\hline
\end{tabular}

A fogmosási szokásokat tekintve a kísérleti csoportban a résztvevők $50 \%$-a jelezte, hogy naponta kétszer, 29\%-a napi egyszer, 21\%-a pedig alkalmanként mosott csak fogat. A kontroll csoportban ugyanezek az értékek 69, 24 és 7\%-nak bizonyultak. Egyéb szájhigiénés eszközt, saját bevallása szerint, a kísérleti csoport 20\%-a, a kontroll csoport 31\%-a használt rendszeresen. Fogorvoshoz járási szokásaikra rákérdezve, a kísérleti csoportban $51 \%$, a kontroll csoportban pedig $65 \%$ válaszolta azt, hogy rendszeresen ellenőrizteti a fogait.

Az általános adatok csoporton belüli megoszlását és a csoportok közti összehasonlítását a 2. táblázat mutatja. Az OHIP-14 kérdőív segítségével öt témakörben szerepeltek a kérdések. Az öt kérdéskörnek megfelelően a válaszok átlagértékeit és azok szórását a 3. táblázat mutatja be. Ennek alapján látható, hogy nagyobb átlagértéket találtunk a krónikus parodontitises csoportban, emellett a szórásértékek is magasabbak. A vála- szok legmagasabb értékeivel a szájüregi fájdalomra és az esztétikára utaló kérdéseknél találkozhatunk.

\section{2. táblázat}

Általános adatok összehasonlítása

a krónikus parodontitises és a kontroll csoport között. (A furkációérintettség elemzése során minden személy esetén a legmagasabb értéket vettük figyelembe mint csoportalkotó tényezőt,

és az adott fokú érintettséggel rendelkező személyek számát osztva a csoportlétszámmal, kaptuk meg a táblázat százalékos értékét.)

\begin{tabular}{|c|c|c|}
\hline & $\begin{array}{c}\text { Kísérleti csoport } \\
\text { (29 fő) }\end{array}$ & $\begin{array}{c}\text { Kontroll csoport } \\
\text { (16 fő) }\end{array}$ \\
\hline Életkor (év) & $45,45 \pm 13,69$ & $34,56 \pm 16,45$ \\
\hline \multicolumn{3}{|l|}{ Nemek százalékos aránya } \\
\hline Férfi (\%) & 51,72 & 31,25 \\
\hline Nő (\%) & 48,28 & 68,75 \\
\hline Fogak száma (db) & $21,59 \pm 6,16$ & $24,31 \pm 5,94$ \\
\hline Plakk index (\%) & $47,7 \pm 19,2$ & $26,9 \pm 15,3$ \\
\hline Fogkő index & $0,55 \pm 0,41$ & $0,31 \pm 0,22$ \\
\hline Ínyvérzési index (\%) & $39,5 \pm 23$ & $23,7 \pm 14$ \\
\hline Szondázási mélység (mm) & $3,75 \pm 1,13$ & $2,07 \pm 0,80$ \\
\hline Ínyrecesszió (mm) & $0,71 \pm 0,49$ & $0,29 \pm 0,17$ \\
\hline Furkációérintettség (\%) & $\begin{array}{c}0 \text { fokú: } 9 \% \text {, } \\
\text { I: } 58 \% \text {, II: } 29 \% \text {, } \\
\text { III: } 4 \%\end{array}$ & 0 fokú: $100 \%$ \\
\hline Mobilitás $(0,1,2,3)$ & $0,57 \pm 0,23$ & $0,27 \pm 0,19$ \\
\hline
\end{tabular}

3. táblázat

A parodontitises csoport és a kontroll csoport kérdésköreire adott válaszok értékeinek az összehasonlítása. $A$ válaszok 4, 3, 2, 1, 0 pontos értékeiból számoltunk átlagot, a „mindig” 4 pontot, a „soha” válasz 0 pontot jelentett (lásd a szövegben).

\begin{tabular}{|l|c|c|}
\hline & $\begin{array}{c}\text { Krónikus parodontitises } \\
\text { csoport } \\
\text { (átlag } \pm \text { SD) }\end{array}$ & $\begin{array}{c}\text { Kontroll } \\
\text { csoport } \\
\text { (átlag } \pm \text { SD) }\end{array}$ \\
\hline $\begin{array}{l}\text { Funkcionális } \\
\text { korlátozottság }\end{array}$ & $0,76 \pm 0,87$ & $0,06 \pm 0,25$ \\
\hline Szájüregi fájdalom & $1,41 \pm 0,98$ & $0,44 \pm 0,63$ \\
\hline Komfortérzet & $0,86 \pm 0,87$ & $0,12 \pm 0,34$ \\
\hline Esztétika & $1,17 \pm 0,93$ & $0,25 \pm 0,58$ \\
\hline $\begin{array}{l}\text { Mindennapi } \\
\text { tevékenységek } \\
\text { korlátozottsága }\end{array}$ & $0,61 \pm 0,83$ & $0,12 \pm 0,34$ \\
\hline
\end{tabular}

Vizsgálatunk során szoros összefüggést találtunk a parodontális kórképek jelenléte és az esztétika között $(p=0,003)$. A kényelmetlenség-érzés $(p=0,023)$, a fájdalom jelenléte $(p=0,021)$ és a funkcionális korlátozottság $(p=0,023)$ kisebb, de határozott kapcsolatot mutat a fogágybetegség jelenlétével. A probléma jelenléte a mindennapi tevékenységek végzése során 
viszont nem mutatott kapcsolatot az életminőség romlásával a parodontitises betegek esetén.

A szájüregi fájdalomra vonatkozó válaszok nem függtek össze a hiányzó fogak számával (32 fogra viszonyítva $p=0,12,28$ fogra viszonyítva $p=0,81$ ), viszont kapcsolatban álltak az ínyvérzéssel $(p=0,041)$, a szondázási mélységgel, a hátsó $(p=0,002)$ és az elülső $(p=0,003)$ régióban is. A legszorosabban a szondázási mélységgel mutatott kapcsolatot. A funkcionális korlátozottság szignifikáns korrelációt mutat a hiányzó fogak számával (32 fogra és 28 fogra viszonyítva is mindkét esetben $p=0,001)$, az ínyvérzéssel ( $p=$ 0,012 ), és ebben a kérdéskörben is a szondázási mélységgel a posterior $(p=0,00)$ és az anterior $(p=0,007)$ régióban mutatja a legszorosabb összefüggést. A mindennapi tevékenység akadályoztatására utaló kérdések nem mutattak kapcsolatot egyik értékkel sem.

Az esztétikai irányultságú kérdések a szondázási mélységgel mutattak szoros összefüggést. Nem sikerült azonban összefüggést kimutatni az esztétikai vonatkozású problémák és az ínyvérzés, valamint a foghiány között (ennek egyik oka lehetett, hogy a frontfogak hiányával rendelkezőket nem vontuk be a vizsgálatba).

A parodontológiai vizsgálat során rögzítettük a furkációérintettségre és a fogmobilitásra vonatkozó adatokat is, ezeket azonban nem lehetett összefüggésbe hozni a kérdőíves válaszokkal a negatív leletek döntő többsége miatt.

\section{Megbeszélés}

A krónikus destruktív fogágybetegség multifaktoriális kórkép, kialakulását, fennállását és lefolyását vagy progresszióját különböző, esetenként egymástól teljesen független tényezők befolyásolják. A krónikus folyamat során tapadásveszteség jöhet létre, amit több magatartási tényező (szájhigiéné, dohányzás, stressz, táplálkozás), helyi plakkretenciós tényezők, genetikai és szervezeti rizikófaktorok (immunállapot, hormonális tényezők, életkor, etnikai hovatartozás) súlyosbíthatnak [4, 9]. Papaioannou és mtsai [25] vidéki és városi populáció összehasonlításakor a két csoportban nem találtak különbséget a parodontális kórképek orális életminőségre gyakorolt hatásai között, az iskolázottságnak azonban sikerült kimutatni a pozitív ráhatását. $A$ nemi hovatartozásnak összetett hatása van. Klinikailag azonos manifesztációval rendelkező kórképek nők esetében nagyobb hatással vannak az életminőségi mutatókra [17], másrészt a férfiaknál nagyobb az esély a parodontális tapadásveszteség kialakulására [14]. Hermann és mtsai szerint a magyarországi nők egészségtudatossága nagyobb, több szájhigiénés eszközt alkalmaznak és azokat gyakrabban is használják, mint a férfiak [12].

Az Oral Healt Impact Profile (OHIP) rövidített, 14 kérdésből álló kérdőív fogágybetegségekre irányuló kérdésekkel bővített változatával, a páciens orális életminőségét határoztuk meg a parodontális státusszal összevetve. A vizsgálat eredményei a szakirodalmi adatoknak megfelelően $[2,8]$ arra utalnak, hogy a parodontális megbetegedések szoros kapcsolatban állnak az esztétikával, a kényelmetlenség-érzéssel, a fájdalom jelenlétével és a funkcionális korlátozottsággal, viszont nincsenek szignifikáns hatással a mindennapi általános tevékenységre. A szondázási mélység statisztikai eredményei kapcsolatba hozhatók a szájüregi fájdalmak, a funkcionális korlátozottság és az esztétikai problémák, illetve az ezekkel kapcsolatos diszkomfort érzés előfordulásával. A betegek parodontológiai leleteinek egyéb jellemzőit illetően a foghiánynak és a szondázásra jelentkező vérzésnek volt szignifikáns, hasonló kapcsolata a funkcionális korlátozottsággal. Esztétikai vonatkozású eredményeink részben korrelálnak a Zanatta és mtsai [35] által közöltekkel, akik rögzített fogszabályozó kezelések hatását vizsgálva, a frontális zónában fellépő ínyelváltozásokkal kapcsolatban gyakrabban találtak esztétikai és pszichés negatív hatásokat, mint a hátsó zónában. $A$ részleges eltérésben feltételezhetően szerepet játszik a vizsgált populációk korának és esztétikai érzékenységének különbözősége is. A furkációérintettség, valamint a fogmobilitás klinikai paraméterei nem mutattak statisztikai összefüggést az életminőségre vonatkozó kérdésekkel. Borges és mtsai [5] ezzel ellentétben azt találták, hogy a rögzítő apparátus gyengülése csökkenti a rágás effektivitását, és negatívan befolyásolja az életminőséget.

Az életminőség általános jellemzői közül csupán a mindennapi tevékenységek akadályozottsága volt az, amely nem mutatott szoros kapcsolatot egyetlen fizikális vizsgálati lelettel sem. Ez összhangban van nemzetközi vizsgálatok eredményeivel is $[14,18]$.

Mivel szoros összefüggés feltételezhető az életminőség bizonyos paramétereinek csökkenése és a parodontális kórképek fizikális vizsgálati leletei között, indokoltnak tünik, hogy a fogágybetegek klinikai vizsgálata során életminőségre vonatkozó kérdéseket is rutinszerűen feltegyünk betegeinknek. A kérdőív használata segítheti a gyakorló fogorvost abban, hogy a beteg minél professzionálisabb ellátást kapjon, illetve az orvos pontosabb diagnózist állíthasson fel a beteg válaszaiból nyert plusz információval. Arra is következtethetünk, hogy az idejében elvégzett parodontológiai kezelés - az egészségi állapot javulásán keresztül kedvező hatást gyakorolhat a betegek életminőségére [29]. Meg kell jegyeznünk azonban azt is, hogy az általunk talált statisztikai összefüggések nem feltétlenül jelentenek ok-okozati kapcsolatot a vonatkozó klinikai és életminőségi paraméterek között, így a kérdéskör további tisztázása céljából újabb vizsgálatokat tartunk indokoltnak.

Mivel a vizsgálati módszer a diagnózis szempontjából alapvető, ezért különösen nyomatékosítjuk a következő módszertani vonatkozásokat. Jelen közleményünkben egy adott populáció keresztmetszeti epidemiológiai jellegű vizsgálatának eredményét dolgoztuk fel. A szakirodalomban - célszerüségük alapján - eltérő vizsgáló 
módszereket alkalmaznak epidemiológiai- és szürővizsgálati tudományos munkákban, valamint randomizált intervenciós klinikai vizsgálatokban. Amíg randomizált klinikai vizsgálatokban a részletes, foganként hat mérési területen végzett módszert célszerủ alkalmazni, addig a nagyobb esetszámmal dolgozó epidemiológiai munkákban egyszerüsített módszereket használnak. Az egyszerúsített vizsgálatok előnyeit és hátrányait részleges parodontológiai regisztrációs módszerek [33] elnevezés alatt tárgyalja a szakirodalom. Ezek alapján epidemiológiai közleményekben alkalmaznak 1, 2, 3 és 4 pontos regisztrációt, speciális indexeket használó vizsgálati protokollokat (például Ramfjord-féle parodontális index, CPI index), illetve végezhetik a regisztrációt csak meghatározott kvadránsokban is [33]. Vizsgálatunkhoz a foganként 4 ponton történő módszert választottuk [7], mert megbízhatónak és egyben kellően egyszerünek tartjuk. Hangsúlyozni kívánjuk azonban, hogy a klinikai tudományos vizsgálatok és a fogorvosi gyakorlat számára az eredményesség céljából mi is a teljes fogazatot érintő hatpontos regisztrációt, illetve az úgynevezett sétáló szondázási módszert tartjuk optimálisnak és követendőnek. Ugyanakkor fontosnak tartjuk a jelen típusú vizsgálatokat is, hiszen ezek segítségével egyrészt jobban megérthetjük betegeink panaszait, másrészt azokat a motivációs tényezőket, amelyek fogorvoshoz viszik őket, valamint fokozzák együttmüködő készségüket.

\section{Irodalom}

1. Ainamo J, Bay I: Problems and proposals for recording gingivitis and plaque. Int Dent J 1975; 25: 229-235.

2. Al Habashneh R, Khader YS, Salameh S: Use of the Arabic version of Oral Health Impact Profile-14 to evaluate the impact of periodontal disease on oral health-related quality of life among Jordanian adults. J Oral Sci 2012; 54: 113-120.

3. Atchison KA, Dolan TA: Development of the Geriatric Oral Health Assesment Index. J Dent Educ 1990; 54: 680-687.

4. BAEHN PC, BourgeoIs DM: Epidemiology of periodontal health and disease. In: LANG NP, AtTStrom R, LöE H (eds.): Proceeding of the European Workshop on Mechanical Plaque Control. Quintessence Book 1998; 19-34.

5. Borges tF, Regalo S C, Taba M Jr, Siéssere S, Mestriner W Jr, SEMPRINI M: Changes in masticatory performance and quality of life in individuals with chronic periodontitis. J Periodontol 2013; 84: 325-331.

6. Brennan DS, Spencer AJ: Comparison of a generic and a specific measure of oral health related quality of life. Comm Dent $\mathrm{H} 2005$; 22: $1-8$.

7. Demmer RT, Holtfreter B, Desvarieux M, Jacobs DR Jr, Kerner $W$, NAUCK M, ET AL: The influence of type 1 and type 2 diabetes on periodontal disease progression: prospective results from the Study of Health in Pomerania (SHIP). Diabetes Care 2012; 35: 20362042.

8. Durham J, Fraser hM, McCracken Gi, Stone KM, John MT, PreSHAW PM: Impact of periodontitis on oral health-related quality of life. J Dent 2013; 41: 370-376.

9. Gera I: A fogágybetegség rizikótényezői és szerepük a fogágybetegség pathomechanizmusában. In: GERA I. (szerk.): Parodontológia. Semmelweis, Budapest, 2005; 95-113.
10. Greene JC, Vermillion JR: The simplified oral hygiene index. $J$ Am Dent Assoc 1964; 68: 7-13.

11. Hamp SE, Nyman S, Lindhe J: Periodontal treatment of multirooted teeth. Results after 5 years. J Clin Periodontol 1975; 2: 126135.

12. Hermann P, Borbély J, Gera I, Fejérdy P, Soós B, Madléna M: A hazai felnőtt lakosság fogágyállapotának és a parodontális státuszt befolyásoló rizikótényezők összefüggéseinek vizsgálata. Fogorv Szle 2011; 104: 39-47.

13. Hodacová L, Smejkalová J, Cermáková E, Slezák R, Jacob V, HLAVÁCKOVÁ E: Oral health-related quality of life in Czech population. Cent Eur J Public Health 2010; 18: 76-80.

14. Hyman JJ, ReID BC: Epidemiologic risk factors for periodontal attachment loss among adults in the United States. J Clin Periodontol 2003; 230-237.

15. John MT, Hujoel P, Miglioretti D, LeResche L, Koepsell tD, MiCHEELIS W: Dimension of Oral health related Quality of Life. J Dent Res 2004; 83: 956-960.

16. Kende D, Szabó Gy, Marada Gy, Szenpétery A: A protetikai terápiás lehetőségek életminőségre gyakorolt hatása. Fogorv Szle 2008; 101: 49-57.

17. Khalifa N, Allen PF, Abu-bakr NH, Abdel-Rahman Me: Psychometric properties and performance of the Oral Health Impact Profile (OHIP-14s-ar) among Sudanese adults. J Oral Sci 2013; 55: 123-132.

18. Kieffer JM, Hoogstraten J: Linking oral health, general health, and quality of life. Eur J Oral Sci 2008; 116: 445-450.

19. LOCKER D: Measuring oral Health: a conceptual framework. Comm Dent H 1988; 5: 3-18.

20. LoCKER D, SLADE G: Oral health and the quality of life among older adults: the oral health impact profile. J Can Dent Assoc 1993; 59: 830-844.

21. López R, BaELum V: Oral health impact of periodontal diseases in adolescents. J Dent Res 2007; 86: 1105-1109.

22. Madléna M, Hermann $P$, Tollas $O$, Gerle J, Fejérdy P: Felnőtt korúak táplálkozási, szájhigiénés és fogorvoshoz járási szokásai kérdőíves felmérés alapján. Fogorv Szle 2007; 100: 91-97.

23. NG SK, LeUNG WK: Oral health quality of life and periodontal status. Community Dent Oral Epidemiol 2006; 34: 114-122.

24. Nyman S, LindHe J: Examination of Patients with Periodontal Disease. In: LindHE J, KARRING T, LANG N. (szerk.): Clinical Periodontology and Implant Dentistry. 4th edition. Blackwell Munksgaard, 2003; 403-413.

25. Papaioannou W, Oulis CJ, latsou D, Yfantopoulos J: Oral healthrelated quality of life of Greek adults: a cross-sectional study. Int J Dent 2011; 2011:360292.

26. Petersen PE: Continuous improvement of oral health in the 21st century: the approach of the WHO Global Oral Health Programme. Community Dent Oral Epidemiol 2003; 31: 24-27.

27. ReISNE S: Dental disease and work loss. J Dent Res 1984; 63 : 1158-1161.

28. Shanbhag S, Dahiya M, Croucher R: The impact of periodontal therapy on oral health-related quality of life in adults: a systematic review. J Clin Periodontol 2012; 39: 725-735.

29. Slade GD, Spencer AJ, Locker D, Hunt RJ, Strauss RP, Beck JD: Variations in the social impact of oral conditions among older adults in South Australia, Ontario, North Carolina. J Dent Res 1996; 75: 1439-1450.

30. SLADE GD, Spencer AJ: Development and evaluation of the oral health impact profile. Community Dent Health 1994; 11: 3-11.

31. SLADE GD: Derivation and validation of a short-form oral health impact profile. Community Dent Oral Epidemiol 1997; 25: 284290.

32. Szabó Gy, Kende D, Marada Gy, Szentpétery A: Életminőség és fogpótlástan. Fogorv Szle 2006; 99: 91-98.

33. Tran DT, Gay I, Du XL, Fu Y, Bebermeyer RD, Neumann AS és MTSAI: Assessment of partial-mouth periodontal examination protocols for periodontitis surveillance. J Clin Periodontol 2014; 41: 846-852. 
34. Wong RM, Ng SK, Corbet EF, Keung Leung W: Non-surgical periodontal therapy improves oral health-related quality of life. J Clin Periodontol 2012; 39: 53-61.
35. Zanatta FB, Ardenghi tM, Antoniazzi RP, Pinto tM, Rösing CK: Association between gingival bleeding and gingival enlargement and oral health-related quality of life (OHRQoL) of subjects under fixed orthodontic treatment: a cross-sectional study. BMC Oral Health 2012; 27: 12-53.

\section{SÁRI KD, KóRódı Á, ANGyal J}

\section{Oral health-related quality of life associations to periodontal conditions}

The clinical form and severity of periodontal of periodontal disorders may have negative effects on oral health related quality of life (OHQoL). The oral health impact profile questionnaire (OHIP-14) is the most frequently used instrument to evaluate the effects of intraoral disorders on the perception of well-being of patients.

The modified OHIP-14 was used with 45 people (29 were in the chronic periodontitis and 16 in the control group) to evaluate the effects of periodontal conditions on OHQoL. In the periodontitis group significantly higher level of impact was observed in questions connected to aesthetics, psychological discomfort, physical pain and functional limitation. Higher periodontal probing depth was frequently associated with self-report of pain either in the anterior or posterior dental regions. There was also a significant correlation between the functional limitation and the number of missing teeth, the bleeding on probing and the probing depth.

It is concluded that the periodontal disorders may have negative effects on certain parameters of OHQoL, hence during periodontal investigation the dental clinician should ask anamnestic questions in relation to quality of life.

Key words: oral health related quality of life, OHIP-14, periodontal diseases 